\title{
The examination of relationship between values and consumer emotional attitudes and inclination to pay more cost: (case study: Marivan citizens and tourists)
}

\author{
Mohammadyan Kamal ${ }^{1}$, Amini Safyar ${ }^{1, a^{*}}$, Mahdieh Omid ${ }^{2, b}$ \\ ${ }^{1}$ Department of Business Management, Islamic Azad University, Sanandaj Branch, Sanandaj, Iran \\ ${ }^{2}$ University of Zanjan, Zanjan, Iran \\ aaminisafyar@gmail.com, ${ }^{\text {b }}$ mahdieh@znu.ac.ir
}

Keywords: functional values; social values; symbolic values; willingness to pay higher cost; luxury goods

\begin{abstract}
This study want to determine the buyer values relationship with willingness to pay higher price. The statistical society includes all of the buyers or luxury goods owners (iPhone mobile and Samsung galaxy) at Marivan city and city settlements and tourists in 2015. Because of the unlimited statistical society based on Morgan table, 384 people were determined as a statistical sample. Study is done by descriptive method from a survey kind. Compilation tool was questionnaire that was based on available random sampling and they were distributed after estimating prestige and perpetuity among respondents. Research gave the questionnaire to persons who were Marivan citizen or tourist and bought luxury goods (iphone mobile and samsung galaxy). It is used content validity method to estimate authenticity and it is used cronbach's Alpha to measure perpetuity question naire that optained 0/895 ammount. After questionnaire completion by applying SPSS 20software and statistical tests, person correlation coefficient and variance analyses and T- test were accounted and analyzed that it's hypothesises test result indicated that there is a relationship with social values variables and functional values with willingness to pay higher cost for luxury goods while there is not a relationship among symbolic values with willingness to pay higher cost for luxury goods.
\end{abstract}

\section{INTRODUCTION}

In recent years, international business increment and international companies attendance load to the wider emergence of different countries products in many world markets(Khan and Bamber,2008). Life higher standards, further power to buy, communication development all over the world and markets globalization contribute to this fact that today people know more than other countries and products and yields(d'Astous and Boujbel,2007). As a result, consumers are obtaining products awareness and service and existing brand all over the world and markets globalization contribute to this fact that today people know more than other countries and products and yields(Wong,2008). As a result, consumers are obtaining products awareness and service and exiting brand all over the world. Luxury brands have different feature and different definitions are given(Miller and Mills,2012). have emphasized on luxury brand's dimensions by referring to competitive definitions. This contain social and individual meanings but they maintain prestige and show it's quality. They expressed various features which is inclusive of identity, awareness, consumer's perception about quality, maintenance ability. And market share access ability and consumer loyalty.

Special brands are determined based on new luxe idioms which show consumer inclinations and goods price is not a preventive factor to buy goods and they show the availability increment all over the world (Granot et al ,2013). defined the luxe goods accessibility on a massive volume with markets that they include service and social respondents and replaced products and necessary goods in market. 
(Miller and Mills,2012). believe that whatever causes the customer enthusiasm to pay higher cost and willingness to pay money voluntarily by consumers, is that consumers accepted it's value. In other words, from the consumer view, product position evaluation has a special role in their willingness to pay more( $\mathrm{Li}$ et al,2013). recognized a mixture a of consumer values as a inclination persuasive to pay more. They referred to enthusiasm relative importance to pay money as a loyalty determinate to brand and main buy function factor. As for Marivan city is a border line cities and being border line and foreign luxury goods entrance provide suitable market for it's tourists and remarkable market prosperity grow the middle class in the city that have more inclination to buy luxury goods therefore their taste determination seems necessary. So the lack of doing such study among internal research's seems tangible. This study fills the existing scientific whit buyer values relationship on willingness to pay more cost for the luxury goods and effective views on consumer facture behavior on luxury brands basis. According to the mentioned issues, general aim of this study is to determine the buyers values relationship and willingness to pay more.

\section{THEORETICAL BASIS}

\section{1. buyers values impact on orient to pay more cost.}

Views which distinguish luxe brands from other market brands, are the costumer's preference about quality and high function. Functional value is about is about brands that and brand quality has positive impact on consumer view and it may increase price to a more cost. such that consumer will have inclination to pay more cost( $\mathrm{Li}$ et al,2013).

\subsubsection{Social values:}

Kim et al proposed social value evaluation to obtain financial consequence image, long social qualification, to be acceptable and to be adoptable with brand. This value factor affects on consumer loyalty to brand remarkably and is indicative of solidarity and versatility in distributed media. Vigneron and Johnson (1999), determined the social value impact on purchase intention that they refer to social values as a consumers harmonic determinants. The relationship between social value and purchase value is recognized by paying attention to luxe fashions. Choo et al (2012), evaluated the goods price as a prestige sign for consumers in their study( $\mathrm{Li}$ et al,2013).

\subsection{2. symbolic value:}

Positive display opportunity of high life standard and harmonic increasing with social circumstances are representative of brand symbolic value features. Based on this view, luxe goods consumer uses this goods as a sublime symbols. Vigneron and Johnson (1999) referred to luxe brands as a symbol and wealth sign and consumer status( Li et al,2013).

\section{THE REVIEW OF ACCOMPLISHED STUDIES AND THEORETICAL FRAMEWORK FORMULATION}

On this basis, some limited studies are done out of the country and it will refer to them and then the theoretical framework and hypo thesis's will be formulated based on the theoretical basis and practical studies. Li et (2013) results show that social values and luxe brands symbolic values have impact on consumers inclination to pay more. Li et al (2012) research results indicate that fashion life method, social/ affective values, utilitarian values and economic values has significant effect on chineese consumer inclination to buy and use goods with luxe brand. Jing Hu et al (2012) results shows that conception of functional suitability, conception of symbolic suitability have positive impact on trade name preference by chineese consumers.

Almaro and Rowley (2012) concluded that brand awareness variables (advertisement, commercial break and mouth to mouth advertisement), brand image(price, quality, factory fame, brand identity and place status) and consumer's features(Satis faction, reference groups and taking risk) can predict brand preference. Mollo and Mrills (2005) results showed that functional and symbolic value's consumers cause the consumer's inclination to choose one brand and from consumer's view about brand function and brand phase, they have role in their tendency to brand preference. Now by summation of theories and practical research findings, we can offer research theoretical model. 


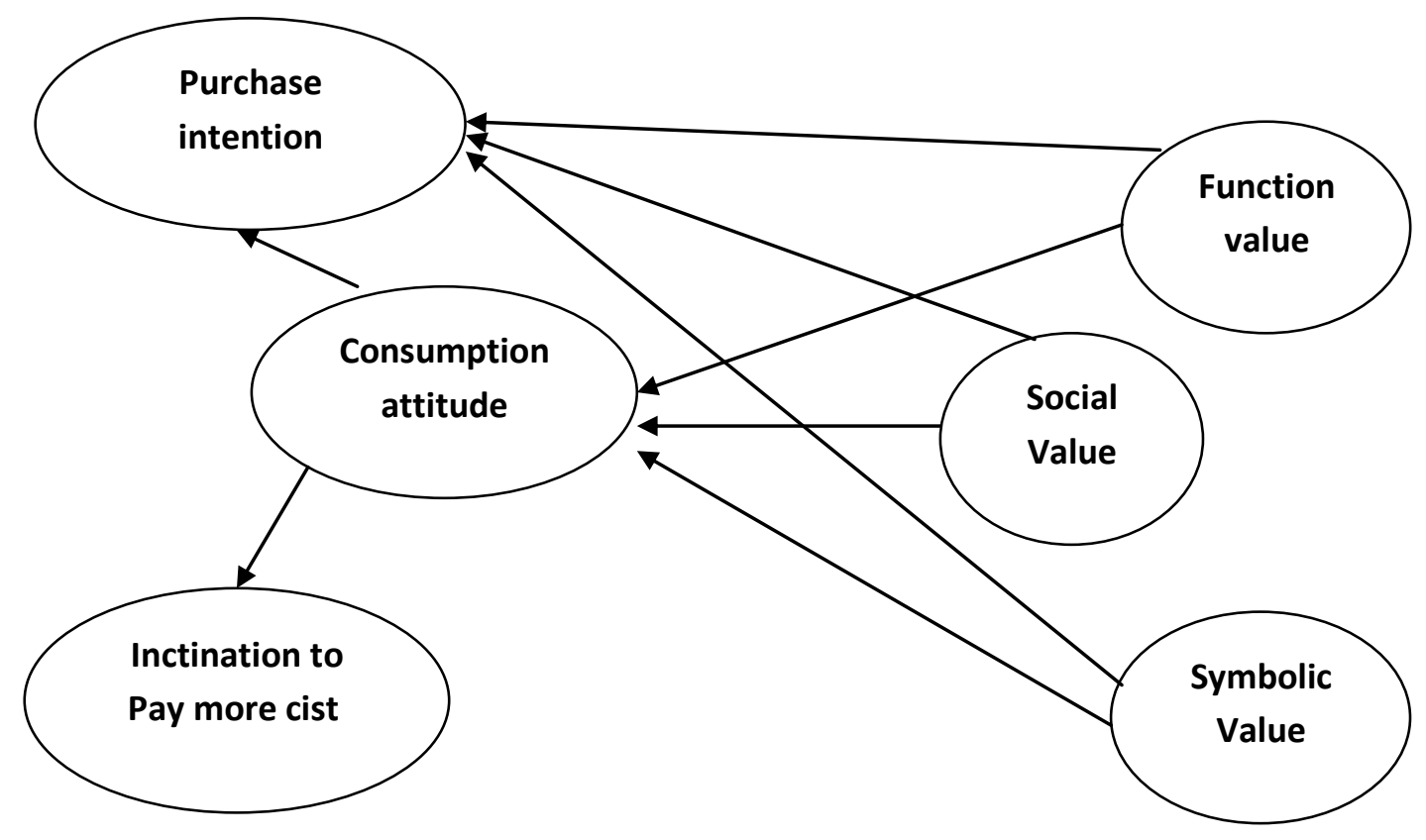

Therefore the hypothesizes of this research is mentioned below:

4. MAIN HYPOTHESIS: relationship between consumer's values with inclination to pay higher cost for luxury goods.

\subsection{Secondary values:}

- There is a relationship between consumer social values with inclination to pay higher cost for luxury goods.

- there is a relationship between consumer symbolic values with inclination to pay higher cost for luxury goods.

\section{METHODOLOGY}

Research method is descriptive and correlation and research statistical society is contained all of the buyers or luxe goods owners (iphone mobile and Samsung galaxy) in Marivan city including of city settlements and tourists in 1393 in a indefinite number. It should be mentioned that because of the unavaibility of the statistical society number and it's indefinite, based on the Morgan table, sample amount is 384 person. By paying attention to the study nature subject and statistical society, it is used available random sampling. In this study, sample acquisition technique needs some various sample and it will be done in a way that final interview cost gets minimum. First, a sample will be selected among the areas then will be referred to stores, shops and Tourism places and public places and persons who wanted to purchase iphone mobile and Samsung galaxy, are selected as a available samples and questionnaires will be filled by them. Questionnaire was the compilation tool that was distributed after the validity estimation and perpetuity among respondents. To measure the cousumer's currencies and it's impact on inclination to pay higher cost, it is used questionnaires in Li et al (2013) and Jing Hu et al (2012) English articles. Cronbach's Alpha amount was obtained $0 / 895$ in questionnaire. To analyze data, it is used descriptive statistical analysis methods (including tables and graphs, central attitude indices, frequencies, diffusion, ...) and inferential statistic analysis methods (Pearson correlation correlation coefficient $\mathrm{T}$ and $\mathrm{F}$ test). Statistical tests are done by the SPSS software packages.

\section{FINDINGS}

\section{1. hypothesizes test:}

1. (functional values), 2. (symbolic values), 3. (consumer's social values have relationship. It is used pearson significancy test to examine this hypothesis and optained results show that there is a 
relationship between consumer's values variables and inclination to pay more cost for luxury goods in a significance level (sig: 0/000). The relationship correlation intensity between this tow variable is $\% 5 / 5$ which is strong with inclination to pay higher cost for luxe goods.

And the type of correlation between this two variable is positive (direct) and the accounted significance level (sig: $0 / 000)$ is less than study Alpha $(\alpha=0 / 05)$ which is indicative of the significance relationship between this two mentioned variable. As a result, according to the result, we can say that there is a relationship between consumer values with inclination to pay higher cost for luxury goods. Therefore, the research main hypothesis and secondary hypothesizes are confirmed. results are shown in table 1.

Table: 1 The correlation test of consumer's values relationship with inclination to pay higher cost for luxe goods

\begin{tabular}{|c|c|c|c|c|}
\hline \multicolumn{3}{|c|}{$\begin{array}{l}\text { Dependent variable: inclination to pay more cost for luxe } \\
\text { goods }\end{array}$} & \multirow{2}{*}{\multicolumn{2}{|c|}{ Independent variable }} \\
\hline Result & significance & correlation intensity & & \\
\hline Confirmed & 0.000 & 0.441 & Functional values & \multirow{3}{*}{$\begin{array}{l}\text { Consumer } \\
\text { Values } \\
\text { dimensions }\end{array}$} \\
\hline Confirmed & 0.000 & 0.647 & Social values & \\
\hline Not Confirmed & 0.586 & 0.028 & Symbolic values & \\
\hline confirmed & 0.000 & 0.551 & \multicolumn{2}{|c|}{ Main hypothesis: consumer values } \\
\hline
\end{tabular}

\section{CONCLUSION}

Result should that consumer values have relationship with inclination to pay more cost for luxe goods. The obtained results of this hypothesis are consistent with the Li et al results and the results confirm the studies. Based on the consumer functional values results have relationship with inclination to pay more cost for luxury goods. The obtained results of this hypothesis are consistent with the $\mathrm{Li}$ et al result and the results have relationship with inclination to pay more cost for luxury goods. The obtained results of this this hypothesis is consistent with the result of the Li et al (2012) and Jing $\mathrm{Hu}$ et al (2012) studies. Functional value is about brands that estimates predetermined functional levels or exceeds them. It is affected on brand quality about consumer view and it may increase the price to a higher amount such that consumers have inclination to pay higher cost to satisfy this requirement. Based on the consumer social values result, there is a relationship with inclination to pay more cost for luxury goods. The obtained result of this hypothesis are consistent with the results of the $\mathrm{Li}$ et al (2013), Li et al (2012) results and results confirm this study. Parallel with obtained results of this hypothesis, it must be said that Kim et al (2012) proposed the social value evaluation with financial consequence image acquisition, long social circumstance and adaptability with brand. This valuable factor affects on the consumer loyalty to brand and it is indicative of solidarity and versatility in distributed media. It is long time that social value effect is determined by Vignernon and Johnson (1999) that they referred to social values as consumers harmonic determinants.

The relationship between social value and purchase value and purchase value is recognized according to the luxe fashions. Chu et al (2013) evaluated the goods price as a prestige sign for the consumers in his study. The findings obtained from the Pearson correlation test showed that consumer symbolic values variables and inclination to pay more cost for luxe goods don't have significance correlation. Therefore the third secondary hypothesis is rejected. The findings of this hypothesis are consistent with Li et al (2013), Li et al (2012) and the results confirm this studies but they are not consistent with the Jing Hu et al (2012). This hypothesis is not confirmed but it should say that high life standard display opportunity. And increment of harmony with selected social conditions are representative of brand symbolic value features. Based on this view, luxe goods consumer uses this goods as proud symbols.

Vignernon and Johnson (1999) referred to the luxe goods as a symbol and wealth sign and consumers position. Generally, people use the prestige brands products to show their position. This people pay a lot of money to purchase this products while this products may have less value but this 
people have inclination to buy such products. In fact, if the price of a product is higher than natural standards, if the price of a product is higher than natural standards, it's prestige value will be higher. Based on the obtained results, it may be suggested that factor such as the applied technology in yield production, product necessity have roles in buyer values.

So the manufacturers of luxe good should pay attention to this items in their production line.

Our society people should select their production pattern based on their need, social class and their economic base. The correct consumption must be shown in an informal education ways by public medic such as radio and TV. The aim of media advertisement's should not be advertisement for commercial goods but it should include values related to the Iran society culture identity.

Advertisements which consider cultural, national and civilization values, should be encouraged.

\section{Reference list}

[1] Ibrahim, Abdolhamid, Jafarzadeh, Mehdi, Bozorgi, saber ., The examination of effective factors on motivation and consumers intention on fake products purchase of luxe brands in cloth industry. Novin marketing research's, 6(1)(2012).

[2] Alamro, A., \& Rowley, J., Antecedents of brand preference for mobile telecommunications services. Journal of Product \& Brand Management, 20(6)(2011).

[3] Choo, Ho Jung, et al. ,'Luxury customer value', Journal of Fashion Marketing and Management, $16(1(2012)$.

[4] d'Astous, A.; Boujbel, L., Positioning Countries on Personality Dimensions:Scale Developmentand Implications for Country Marketing, Journal of Business Research, 60(3)(2007).

[5] Granot, E., Russel, L.T.M. and Brashear-Alejandro, T.G., Populence: exploring luxury for the masses, Journal of Marketing Theory \& Practice, 21(1)(2013).

[6] Jing Hu and Xin Liu \& Sijun Wang \& Zhilin Yang ,. The role of brand image congruity in Chinese consumers' brand preference,Journal of Product \& Brand Management,21(1)(2012).

[7] Khan, H.; Bamber, D.,Country of Origin Effects, Brand Image, and Social Status in an Emerging Market. Human Factors and Ergonomics in Manufacturing.5(2008).

[8] Kim, Mijeong, Kim, Sookhyun, and Lee, Yuri., 'The effect of distribution channel diversification of foreign luxury fashion brands on consumers' brand value and loyalty in the Korean market', Journal of Retailing and Consumer Services, 17(4)(2010).

[9] Li, Guoxin, Li, Guofeng, and Kambele, Zephaniah., 'Luxury fashion brand consumers in China: Perceived value, fashion lifestyle, and willingness to pay', Journal of Business Research, 65(10)(2012).

[10] Li, Ning, Robson, Andrew, and Coates, Nigel ,.'Chinese consumers' purchasing: impact of value and affect', Journal of Fashion Marketing and Management, 17(4)(2013).

[11] Miller, K.W. and Mills, M.K., Probing brand luxury: a multiple lens approach, Journal of Brand Management, 20(1) (2012).

[12] Mowle, J. and Merrilees, B., A functional and symbolic perspective to branding Australian SME wineries, Journal of Product \& Brand Management, 14(4)(2005).

[13] Vigneron, Franck and Johnson, Lester .W ., 'A review and a conceptual framework of prestigeseeking consumer behavior', Academy of Marketing Science Review, 1(1)(1999).

[14] Wong, Y.; Polonsky, C.; Garma, J.; Romana, M.,"The impact of consumer ethnocentrism and country of origin sub-components forhigh involvement products onyoung Chinese consumers'product assessments, Asia Pacific Journal of Marketing and Logistics, 20( 4)(2008). 